University of Nebraska - Lincoln

DigitalCommons@University of Nebraska - Lincoln

\title{
Survival, dispersal, and home-range establishment of reintroduced captive-bred puaiohi, Myadestes palmeri
}

\author{
Erik J. Tweed \\ USGS Biological Resources Division \\ Jeffrey T. Foster \\ USGS Biological Resources Division \\ Bethany L. Woodworth \\ bethany_woodworth@usgs.gov \\ Paul Oesterle \\ Zoological Society of San Diego \\ Cynthia Kuehler \\ Zoological Society of San Diego, KuehlerC@prodigy.net \\ See next page for additional authors
}

Follow this and additional works at: https://digitalcommons.unl.edu/usgsstaffpub

Tweed, Erik J.; Foster, Jeffrey T.; Woodworth, Bethany L.; Oesterle, Paul; Kuehler, Cynthia; Lieberman, Alan A.; Powers, A. Tracey; Whitaker, Kristin; Monahan, William B.; Kellerman, Jherime; and Telfer, Tom, "Survival, dispersal, and home-range establishment of reintroduced captive-bred puaiohi, Myadestes palmeri" (2003). USGS Staff -- Published Research. 577.

https://digitalcommons.unl.edu/usgsstaffpub/577

This Article is brought to you for free and open access by the US Geological Survey at DigitalCommons@University of Nebraska - Lincoln. It has been accepted for inclusion in USGS Staff -- Published Research by an authorized administrator of DigitalCommons@University of Nebraska - Lincoln. 


\section{Authors}

Erik J. Tweed, Jeffrey T. Foster, Bethany L. Woodworth, Paul Oesterle, Cynthia Kuehler, Alan A. Lieberman, A. Tracey Powers, Kristin Whitaker, William B. Monahan, Jherime Kellerman, and Tom Telfer 


\title{
Survival, dispersal, and home-range establishment of reintroduced captive-bred puaiohi, Myadestes palmeri
}

\author{
Erik J. Tweed ${ }^{\mathrm{a}}$, Jeffrey T. Foster ${ }^{\mathrm{a}, 1}$, Bethany L. Woodworth ${ }^{\mathrm{a}, *}$, Paul Oesterle ${ }^{\mathrm{b}}$, \\ Cynthia Kuehler ${ }^{\mathrm{b}}$, Alan A. Lieberman ${ }^{\mathrm{b}}$, A. Tracey Powers ${ }^{\mathrm{b}}$, Kristin Whitaker ${ }^{\mathrm{b}}$, \\ William B. Monahan ${ }^{\mathrm{a}, 2}$, Jherime Kellerman ${ }^{\mathrm{a}, 3}$, Tom Telfer ${ }^{\mathrm{c}}$ \\ ${ }^{a}$ USGS Biological Resources Division, Pacific Island Ecosystems Research Center, Kilauea Field Station, PO Box 44, Building 344, \\ Hawaii National Park, HI 96718, USA \\ ${ }^{\mathrm{b}}$ Zoological Society of San Diego, Hawaii Endangered Bird Conservation Program, Volcano, HI 96785, USA \\ ${ }^{\mathrm{c}}$ Hawaii Division of Forestry and Wildlife, Department of Land and Natural Resources, Lihue, HI 96766, USA
}

Received 1 October 2001; received in revised form 15 May 2002; accepted 23 May 2002

\begin{abstract}
We monitored the survival, dispersal, and home-range establishment of captive-bred, reintroduced puaiohi Myadestes palmeri, a critically endangered thrush endemic to the island of Kauai. Fourteen captive-bred, juvenile birds were released from hacktowers in January-February 1999 and monitored for 8-10 weeks using radiotelemetry. All 14 birds (100\%) survived to 56 days post-release. Two birds (14.3\%) dispersed greater than $3 \mathrm{~km}$ from release site within 1 day of release. The remaining birds settled within 1 week and established either temporary home-ranges (mean area $=7.9 \pm 12.0$ ha, range $0.4-31.9$ ) or breeding home-ranges (mean area $1.2 \pm 0.34$ ha, range $0.8-1.6$ ). Temporary home ranges were abandonded by the beginning of the breeding season, and ultimately 6 of the 14 birds (43\%) established breeding home ranges in the release area. The high survival rate bodes well for establishing additional populations through captive breeding and release; however, the 57\% dispersal rate out of the target area means that several releases of birds may be necessary in order to repopulate a given drainage. Furthermore, observed dispersal and gene flow between the reintroduced and wild populations have important implications for management of the captive flock.

Published by Elsevier Science Ltd.
\end{abstract}

Keywords: Reintroduction; Captive-bred; Puaiohi; Dispersal; Home-range

\section{Introduction}

Managers have recently turned to translocations and reintroductions of bird species to formerly occupied habitat as a technique to restore, save, or bolster dwindling populations (e.g. Rudolph et al., 1992; Sanz and Grajal, 1998; Armstrong et al., 1999). The success or failure of reintroductions is dependent upon short

\footnotetext{
* Corresponding author. Tel.: + 1-207-799-7805; fax: + 1-207-7996786.

E-mail address: bethany_woodworth@usgs.gov (B.L. Woodworth).

${ }^{1}$ Present address: Program in Ecology and Evolutionary Biology, University of Illinois, Urbana, IL 61820, USA.

2 Present address: Museum of Vertebrate Zoology, 3101 Valley Life Sciences Building, University of California, Berkeley, CA 94720-3160, USA.

3 Present address: SCE NRO NALF SCI, PO Box 357054, San Diego, CA 92135-7054, USA.
}

and long-term processes, e.g. processes acting during the establishment phase immediately following release (survival and dispersal behavior of released birds), and population dynamics processes such as long-term survival rates and breeding success (Armstrong et al., 1999). Data on these various components of success are important because they allow the identification of the mechanisms responsible for success or failure of release efforts (Griffith et al., 1989; Armstrong et al., 1999). However, despite widespread acknowledgement of their importance, adequate post-release monitoring studies are rarely done (Short et al., 1992).

Translocated populations often have a period of high mortality following release (Kurzejeski and Root, 1989; Lovegrove, 1992; Wilson et al., 1992; Musil et al., 1993; Armstrong and Craig, 1995; Castro et al., 1995b). During the establishment phase, mortality may be higher than normal due to stress, injury, or inexperience of the released birds, and this mortality should be 
distinguished from the long-term "background level" of mortality (Armstrong et al., 1999). High mortality is of concern because it has important implications for the probability of survival of the founder population, and suggests that translocation or release methodologies might be improved, either to decrease stress and injury to birds (e.g. antennae type, Dougill et al., 2000; leg band type, Armstrong et al., 1999), or to improve adjustment to the new location. Provisioning with supplemental food is one method by which the transition to free-living can be 'softened', although it does not appear to be necessary in all cases (e.g. saddlebacks Philesturnus carunculatus, Armstrong et al., 1999).

Dispersal from a release area is also of concern, because founder populations may disappear or dwindle if released individuals return to their source population or disperse to surrounding areas (Allen et al., 1993; Clarke and Schedvin, 1997). It is important to distinguish dispersal from mortality as a cause for decline in the founder population. In palila, Loxioides bailleui, at least $50 \%$ of translocated individuals returned to their original capture site $>20 \mathrm{~km}$ away within 2-6 weeks of release (Fancy et al., 1997). Similarly, noisy miners Manorina melanocephala dispersed an average of $4.2 \mathrm{~km}$ from their release site (Clarke and Schedvin, 1997) and at least two individuals returned to their capture site 18 $\mathrm{km}$ away. These results suggest that alternative strategies must be used (e.g. Castro et al., 1995a; Fancy et al., 2001). Regardless, intensive post-release monitoring allows us to determine whether a population that disappears following release has succumbed to stochastic demographic processes, increased post-release mortality, or dispersal (Armstrong et al., 1999).

Hawaii bears the ignominious title of endangered species capital of the world. In the past century, bird species in the Hawaiian Islands have particularly suffered. At least $69 \%$ of the native Hawaiian avifauna is extinct (Olson, 1989) and of the currently extant species or subspecies, nearly half (31) are endangered. On the island of Kauai, the relatively large and intact Alakai swamp is the only remaining ecosystem for native forest birds (Fig. 1), and as late as the 1960s still maintained its entire historic avifauna (Richardson and Bowles, 1964; Pratt, 1994). However, five species of critically endangered birds have possibly gone extinct in the last 30 years, including the ou Psittirostra psittacea, akialoa Hemignathus obscurus, kauai oo Moho braccatus, nukupuu Hemignathus lucidus, and kamao Myadestes myandestinus (Engilis and Pratt, 1989; Pyle, 1993; Pratt, 1994; Reynolds et al., 1997; BRD unpublished data). Factors causing population declines include habitat degradation (Cuddihy and Stone, 1990), introduced avian diseases (Warner, 1968; van Riper et al., 1986; Atkinson et al., 1995), and introduced mammalian predators (Atkinson, 1977; Snetsinger et al., 1994). In the past two decades, two hurricanes (Iwa in 1982 and Iniki in 1992) have struck Kauai, further exacerbating the already tenuous existence of many native forest birds.

The puaiohi is a medium-sized (16.5-17.8 cm long, $37.0-43.0 \mathrm{~g}$ ) solitaire-like thrush that exists only in the remote montane rainforests of the island of Kauai. Puaiohi nest primarily on the cliffs of steep-walled stream valleys, and feed on the fruits of native understory trees and shrubs, as well as insects, snails, and other invertebrates (Snetsinger et al., 1999; BRD unpublished data). Although never common historically (Perkins, 1903; Munro, 1944; Richardson and Bowles, 1964), the puaiohi has apparently undergone a drastic range contraction like many of Kauai's native forest birds (Scott et al., 1986). It is currently listed as a federally endangered species and is one of the rarest birds in the United States. Recent estimates suggest a population size of approximately 200-300 individuals, with an estimated $75 \%$ of the population (core population, Fig. 1) restricted to an area less than $10 \mathrm{~km}^{2}$ (Snetsinger et al., 1999). Additional areas of apparently suitable habitat exist outside the core range (Snetsinger et al., 1999; M. Reynolds personal communication; BRD unpubl. data). However, dispersal rates and distances of wild puaiohi are typically small (Snetsinger et al., 1999; USGS/BRD, unpublished data), a factor which may limit its ability to recolonize recovering habitat. As long as the population is small and restricted to a limited area, it will remain at serious risk to demographic and

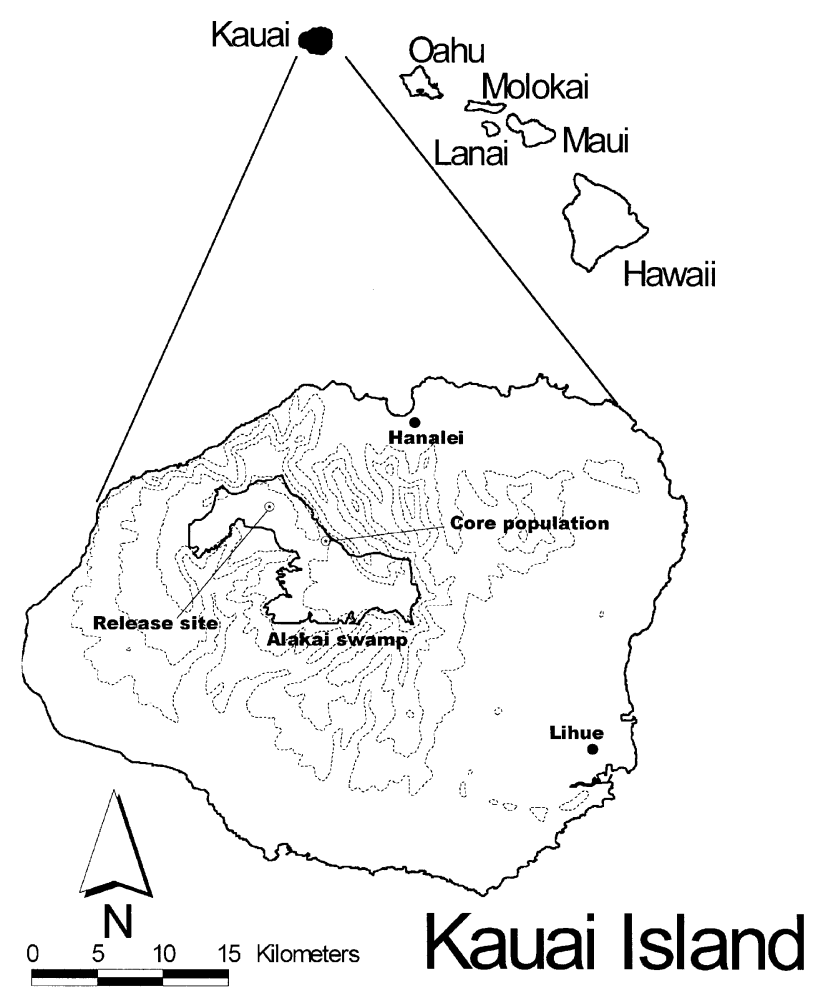

Fig. 1. Locations of the release site and core population in the Alakai swamp, Island of Kauai, Hawaiian archipelago. Relief represented by 1000 -foot contours. 
environmental factors. The goal of establishing a new population outside of the species' current range is to speed habitat recolonization and ultimately recover the species. Here we report on the survival, dispersal, and home-range establishment of captive-bred and released puaiohi, Myadestes palmeri, during the establishment phase.

Reintroduction is a particularly good tool when suitable unoccupied habitat remains and limiting factors can be addressed. The puaiohi, with its ability to utilize a wide variety of food resources and its habit of nesting in ravines, may be more likely to survive hurricanes than many other bird species (Snetsinger et al., 1999). Many areas of the Alakai swamp devastated by Hurricanes Iwa and Iniki are now recovering, and the puaiohi's main food plants are abundant. Furthermore, the remaining Hawaiian thrushes, including the puaiohi, may be developing resistance to avian malaria Plasmodium relictum (Atkinson et al., 2001).

Beginning in 1995, The Peregrine Fund (the Hawaii Program is now managed by the Zoological Society of San Diego, ZSSD), developed methods for hatching, rearing, and releasing Hawaiian thrushes using eggs collected from the omao Myadestes obscurus, the puaiohi's closest living relative (Kuehler et al., 2000). Follow-up monitoring demonstrated that year-old omao reared in captivity from wild-collected eggs demonstrated higher site fidelity than adults translocated from the wild (Fancy et al., 2001). Building on this work, a captive breeding flock of puaiohi was established at ZSSD's Keauhou Bird Conservation Center on Hawaii, using eggs collected from the wild in 1996-1997 (Kuehler et al., 2000).

In 1999, these efforts culminated in the release of 14 captive-bred puaiohi into the lower Kawaikoi drainage, in the western Alakai swamp. We monitored birds during the establishment phase in order to: (1) document causes of mortality among released birds, (2) distinguish dispersal from mortality among the release population, and (3) gain insight into the factors that influence site fidelity and dispersal behavior. Where individuals were reintroduced to the periphery of the species range, it is also important to document movements and interactions between the reintroduced and wild populations, because this has important implications for gene flow and management of the captive flock. Data on components of breeding behavior, nesting success, and survival of released birds through their first breeding season will be presented elsewhere.

\section{Methods}

\subsection{Study site}

Puaiohi were released into former habitat on the northwest edge of the Alakai swamp, Kauai, in the lower Kawaikoi drainage $\left(22^{\circ} 09^{\prime} \mathrm{N}, 159^{\circ} 37^{\prime} \mathrm{W}\right)$ (Fig. 1). Habitat at the release site is primarily wet montane forest dominated by ohia Metrosideros polymorpha with a subcanopy of ohia ha Syzygium sandwichensis, and several species of olapa Cheirodendron spp. Mean annual rainfall is $3000-4000 \mathrm{~mm}$ per year (Giambelluca et al., 1986) and topography consists of a plateau at ca. 1200 $\mathrm{m}$, deeply incised by numerous river drainages.

The release site location was chosen based on several criteria, including: (1) location within the historic range of the species, yet distinct from $(5.5 \mathrm{~km}$ northwest of the wild population, (2) habitat quality and availability of important food plants, (3) relative abundance of the mosquito Culex quinquefasciatus, the primary vector of avian malaria and pox virus Poxvirus avium, (4) relative abundance of introduced predators (rats, Rattus spp., cats, Felis sylvestris, and barn owl, Tyto alba), and a native avian predator (pueo, Asio flammeus sandwichensis), (5) long-term security of the land parcel and potential for beneficial land management actions, (6) public relations, and (7) accessibility for follow-up research. Prior to the release, only two wild puaiohi resided in the release area.

\subsection{Release}

The rearing and release of captive-bred birds were conducted by the ZSSD (Kuehler et al., 2000). Two predator-proof hacktowers (aviaries atop scaffolding) were placed $550 \mathrm{~m}$ apart and releases were alternated between the two hacktowers to minimize interference of birds from earlier releases with birds from subsequent releases. Cohorts were held in the hacktowers for 8-14 days in order for the birds to acclimate to their new environment. A total of 14 captive-bred puaiohi, all less than 1 year old, were introduced to the wild in three separate releases (Table 1). All birds were uniquely color-banded and fitted with lightweight radio-transmitters weighing $<5 \%$ of their bodyweight (model BD$2 \mathrm{G}$, frequency $164.2-165.0 \mathrm{MHz}$, maximum wt. with extra waterproofing and harness $=1.6-1.8 \mathrm{~g}, 8-10$ weeks battery life, Holohil Systems Ltd., Ottawa, Canada). Transmitters were attached using an elastic figure-8 harness (Rappole and Tipton, 1991). Supplemental food, including gathered native fruits, was provided to the birds at the hacktowers for 17 days following release, to ease the transition of birds to the wild. Two males from earlier releases took advantage of supplemental food supplied for later releases. Details of puaiohi captive breeding, rearing, release, and methodology have been presented in Kuehler et al. (2000).

In order to protect birds in the hacktowers and during post-release visits to feeders, we controlled rats and cats in a $300 \times 300 \mathrm{~m}$ grid surrounding each hacktower for 2.5 months prior to the first release. Rodent control was accomplished using a combination of baiting with 
$0.005 \%$ Diphacinone rodenticide in tamperproof bait stations and snap-trapping, and feral cats were removed using live traps. Rodent assessment and control techniques were modeled after investigations in montane rainforest on the island of Hawaii (Nelson et al., 2002) and resulted in a $55 \%$ decrease in rat activity surrounding the hacktowers (BRD, unpublished data). Snap trapping was discontinued after the first release to prevent puaiohi from being accidentally killed in the traps, but baiting was continued through March 1999.

\subsection{Monitoring}

\subsubsection{Radio-telemetry}

The dense forest and behavior of the birds made it necessary to use radio telemetry to document survival and movements. We used headphones and handheld compasses to obtain bearings on radio signals. We used radio signals to obtain triangulated locations for use in estimating dispersal area and identifying when a bird had established a predictable home-range; thereafter, we used radio signals to visually locate birds.

Dispersal locations for the first 4 days were obtained primarily through tri- and quadrangulations. Because released birds were initially "flighty", observers communicated using 2-way radios to obtain simultaneous bearings, thus reducing error associated with signal movement. Bearings were collected throughout each day in $30-60$ min intervals to obtain daily movements and locations. We were able to obtain accurate and precise telemetry locations despite the rugged terrain because established trails throughout the release area allowed us to strategically place several observers, increasing the likelihood of perpendicular bearings, and resulting in less variation in accuracy of our estimated locations (after Deat et al., 1980). Furthermore, distances from the majority of our receiver stations to estimated locations were $<500 \mathrm{~m}$, reducing variation from bearing errors (Deat et al., 1980). Most observers were located high on ridges creating a direct line of sight, reducing the likelihood of signal bounce.

To calculate a constant bearing error and test accuracy within the study area, we compared estimated locations to known transmitter locations $(n=786$ bearings on 262 locations). Thus, we were able to calculate the SD of the mean angular error resulting in a constant bearing error. We used one-way ANOVA to test for variation in bearing error between individual surveyors. Three different estimators were used to calculate locations depending on the number of bearings available for the analysis: the Huber M-estimator for four or more bearings; the Maximum Likelihood Estimator for three

Table 1

Dispersal distances and home-range area size of 14 captive-bred Puaiohi released into the Kawaikoi Drainage, Alakai Swamp, in JanuaryFebruary 1999

\begin{tabular}{|c|c|c|c|c|c|c|c|c|c|c|c|}
\hline \multirow[t]{2}{*}{$\begin{array}{l}\text { Release } \\
\text { cohort }^{\text {a }}\end{array}$} & \multirow[t]{2}{*}{$\begin{array}{l}\text { Bird } \\
\text { ID }\end{array}$} & \multirow[t]{2}{*}{ Sex } & \multicolumn{2}{|c|}{ Duration (days) } & \multicolumn{3}{|c|}{$\begin{array}{l}\text { Home range area in ha } \\
\text { (number of locations) }\end{array}$} & \multicolumn{3}{|c|}{ Dispersal distance in $\mathrm{km}$} & \multirow[t]{2}{*}{$\begin{array}{l}\text { Confirmec } \\
\text { breeding }\end{array}$} \\
\hline & & & $\begin{array}{l}\text { Dispersal } \\
\text { period }\end{array}$ & $\begin{array}{l}\text { Temp } \\
\text { home range }\end{array}$ & $\begin{array}{l}\text { During } \\
\text { dispersal } \\
\text { period }\end{array}$ & Temp & Breeding & $\begin{array}{l}\text { Initial } \\
\text { distance } \\
\text { from release } \\
\text { site }\end{array}$ & $\begin{array}{l}\text { From temp } \\
\text { to breeding } \\
\text { home } \\
\text { range }\end{array}$ & $\begin{array}{l}\text { From release } \\
\text { site to } \\
\text { breeding } \\
\text { home range }\end{array}$ & \\
\hline 1 & 399 & M & 3 & $\mathrm{NA}^{\mathrm{b}}$ & $16.7(17)$ & NA & $1.4(49)$ & 0.02 & NA & 0.5 & $\mathrm{Y}$ \\
\hline 1 & $507^{\mathrm{a}}$ & M & $-^{\mathrm{c}}$ & - & - & - & - & 3.8 & - & - & - \\
\hline 1 & $483^{\mathrm{b}}$ & M & 3 & NA & $2.5(14)$ & NA & $1.6(23)$ & 0.02 & NA & 0.02 & $\mathrm{Y}$ \\
\hline 1 & $458^{\mathrm{c}}$ & M & 6 & 32 & - & $0.4(10)$ & - & 3.9 & - & - & - \\
\hline 1 & 358 & $\mathrm{~F}$ & 3 & 33 & $80.1(18)$ & $6.0(5)$ & - & 1.2 & - & - & - \\
\hline 2 & 530 & $\mathrm{~F}$ & 6 & 31 & $97.1(16)$ & $31.9(7)$ & $1.3(9)$ & 1.4 & 1.3 & 0.5 & $\mathrm{Y}$ \\
\hline 2 & 582 & $\mathrm{~F}$ & 7 & 22 & 220.8 (16) & 4.1 (14) & $1.1(13)$ & 2.1 & 3.2 & 3.9 & $\mathrm{Y}$ \\
\hline 2 & 671 & $\mathrm{~F}$ & 7 & 36 & 102.1 & 4.0 (14) & - & 2.1 & 1.7 & 2.3 & $\mathrm{Y}$ \\
\hline 2 & 697 & $\mathrm{~F}$ & 7 & 44 & $103.7(23)$ & 0.7 (18) & - & 0.3 & - & - & - \\
\hline 2 & $948^{\mathrm{b}}$ & $\mathrm{F}$ & 3 & NA & $56.5(18)$ & NA & $0.8(32)$ & 0.04 & NA & 0.04 & $\mathrm{Y}$ \\
\hline 3 & $419^{\mathrm{a}}$ & M & - & - & - & - & - & $>4.0$ & - & - & - \\
\hline 3 & $749^{c}$ & $\mathrm{M}$ & 5 & 29 & - & - & - & 2.2 & - & - & - \\
\hline 3 & 256 & $\mathrm{~F}$ & 2 & NA & $35.6(19)$ & NA & $0.8(50)$ & 0.4 & NA & 0.4 & $\mathrm{Y}$ \\
\hline 3 & $318^{\mathrm{b}}$ & $\mathrm{F}$ & 1 & NA & $2.9(15)$ & NA & $1.5(13)$ & 0.02 & NA & 0.02 & $\mathrm{Y}$ \\
\hline
\end{tabular}

Release cohort 1 was released on 19 January 1999; 2 released 9 February 1999; 3 released 25 February 1999. NA indicates that the statistic is not applicable (e.g. because the bird did not establish a temporary home range); a dash indicates that data were insufficient to calculate the statistic. Telemetry data were analyzed using Location Of A Signal (LOAS) software (Ecological Software Solutions, 1999).

${ }^{a}$ Birds 507 and 419 each left the study area within $24 \mathrm{~h}$ of release and so it was impossible to calculate statistics for these two birds.

b Birds 483, 948, and 318 ultimately bred on home ranges that encompassed release hack towers.

c For Birds 458 and 749 we were able to calculate the amount of time spent in the dispersal period or on temporary home range, but data were insufficient to calculate home range sizes. 
bearings; and best biangulation for two bearings (Lenth, 1981a,b). A polygon or ellipse with a $95 \%$ confidence interval was calculated for each estimated location. Estimated locations associated with error ellipses or polygons $>5$ ha were excluded from further analyses.

Estimated locations of birds using radio telemetry were imported into ArcView ${ }^{\mathrm{TM}}$ GIS software and analyzed using a fixed kernel home-range estimator to quantify the "dispersal area" (the area the bird covered from release until it "settled down"; dispersal area is an index of the distances a bird covered or its "flightiness"). We generally considered a bird to have settled down when all of its estimated locations were within an area of $<50$ ha, an area which allowed us to consistently locate the bird on consecutive days. Average distance between breeding pairs of wild Puaiohi in the high-density "core" population is only $89 \mathrm{~m}$ along stream valleys (average home range size is not known) (Snetsinger et al., 1999).

\subsubsection{Home-range establishment}

We based our home-range analysis on visual locations of birds after their initial period of dispersal. Radiotracking was used to find the bird during each tracking session and only the first visual observation was used for home-range determination. For birds that remained near a hacktower, home-range determination began only after supplemental food was discontinued on day 17 post-release (no other birds were observed taking supplemental food). We encompassed the range of the birds' circadian activity by recording the initial visual location of birds within the time brackets of 06:00 10:00, 10:00-14:00, and 14:00-20:00 HST (Beyer and Haufler, 1993). Bird locations were determined using a Rockwell GPS unit and only locations with an accuracy of $\pm 12 \mathrm{~m}$ or better were used. Data were analyzed using ArcView ${ }^{\text {TM }}$ GIS software with Spatial Analyst. We used the Animal Movement Extension (USGS/BRD, 1999) to determine home-range size and shape using a fixed kernel home-range estimator. Least squares cross validation was used to determine the value of the smoothing parameter $(H)$. We calculated dispersal distance as the distance between the release hacktower and the center of the home-range, using the arithmetic mean of $X$ and $Y$. Likewise, the distance between a temporary home-range and subsequent breeding home-range was calculated as the distance between the two territory centers. Errors are \pm 1 standard deviation unless otherwise noted.

Temporary home-ranges were identified post hoc as areas that: (1) were occupied prior to the breeding season (which began on 25 March 1999, BRD unpublished data), and (2) were abandoned before or at the start of the 1999 breeding season. Birds that immediately settled in what was to become their breeding home-range were not considered to have had a temporary home-range, and data collection of locations for their breeding home-ranges commenced as soon as that bird was paired and after supplemental food was discontinued.

\section{Results}

\subsection{Survival}

We were able to visually monitor 13 birds for at least 8-10 weeks post-release (battery life of the transmitters). Although not visually confirmed, we considered the remaining bird (a male 419) to still be alive at 8 weeks based on daily movements of radio signals. Thus, all 14 birds $(100 \%)$ survived for 8 weeks following release.

\subsection{Initial dispersal period}

We recorded 1419 bearings on 14 birds for 1-4 days after release. There were no significant differences in bearing error between surveyors (ANOVA $F_{3,36}=2.86$, $P=0.66$ ), so bearings from all observers were pooled to calculate a constant bearing error of \pm 1.89 degrees. The majority of bearings used for this calculation were during the beginning of the field season and it is likely that our bearing error decreased as observers became more experienced with the equipment and terrain. We excluded $25 \%$ of our estimated locations because they were associated with error polygons or ellipses $>5$ ha. Our efforts resulted in 238 estimated locations for the 14 birds, and in 80 instances we confirmed estimated locations by simultaneous or same-day visual confirmation. For these confirmed locations, 77 of $80(97 \%)$ fell within the $95 \% \mathrm{CI}$ associated with the estimated location.

Most released birds displayed a period of initial "flightiness" immediately following release, and ranged throughout portions of the Kawaikoi drainage and neighboring drainages for the first 1-7 days following release (Fig. 2A and Table 1). Birds that eventually established home-ranges at the hacktowers ranged over relatively small areas during this "dispersal period" (mean 22.8 \pm 23.2 ha, range $2.5-56.5, n=5$ ) and settled within $1-3$ days of release (mean $2.4 \pm 0.9, n=5$ ). In contrast, birds that eventually established home-ranges away from hacktowers ranged over significantly wider areas during the dispersal period (mean $120.8 \pm 56.7$ ha, range $80.1-220.8$ ha, $n=5$, Mann-Whitney $U$-test, $z=2.5, P=0.01)$ and took correspondingly longer to settle in temporary home-ranges (mean $5.9 \pm 1.5$ days, range 3-7 days, $n=7$, Mann-Whitney $U$-test, $z=2.5$, $P=0.01)$. We were unable to determine dispersal area for two males or dispersal duration for four males that dispersed out of the Kawaikoi drainage (Table 1). One bird (507) continued to show large unpredictable movements until he permanently left the area 59 days after release. Another male (419) dispersed $>4 \mathrm{~km}$ from the 
release site within $24 \mathrm{~h}$ of release, and although his signal remained active we were unable to obtain sufficient bearings to reliably estimate his location.

\subsection{Home-ranges}

Following the initial dispersal period, seven birds (two males and five females) settled in temporary home-ranges, while five birds (two males and three females) settled immediately in what would become their breeding home-ranges (see methods for definitions of temporary and breeding home-ranges). Temporary home-ranges averaged 7.9 ha in size (SD \pm 12.0 , range $0.4-31.9$ ha, $n=6$, data for one bird were insufficient to calculate home-range size) and were occupied for 22-44 days (mean 29 $\pm 11, n=7$ ). All five females established their temporary home-ranges within the boundaries of the Kawaikoi drainage, while both of the males settled outside the drainage (Fisher exact test, $P=0.048$ ). Two of the seven birds (one female and one male) dispersed from their temporary home-ranges for more than 4 days each, but later returned.
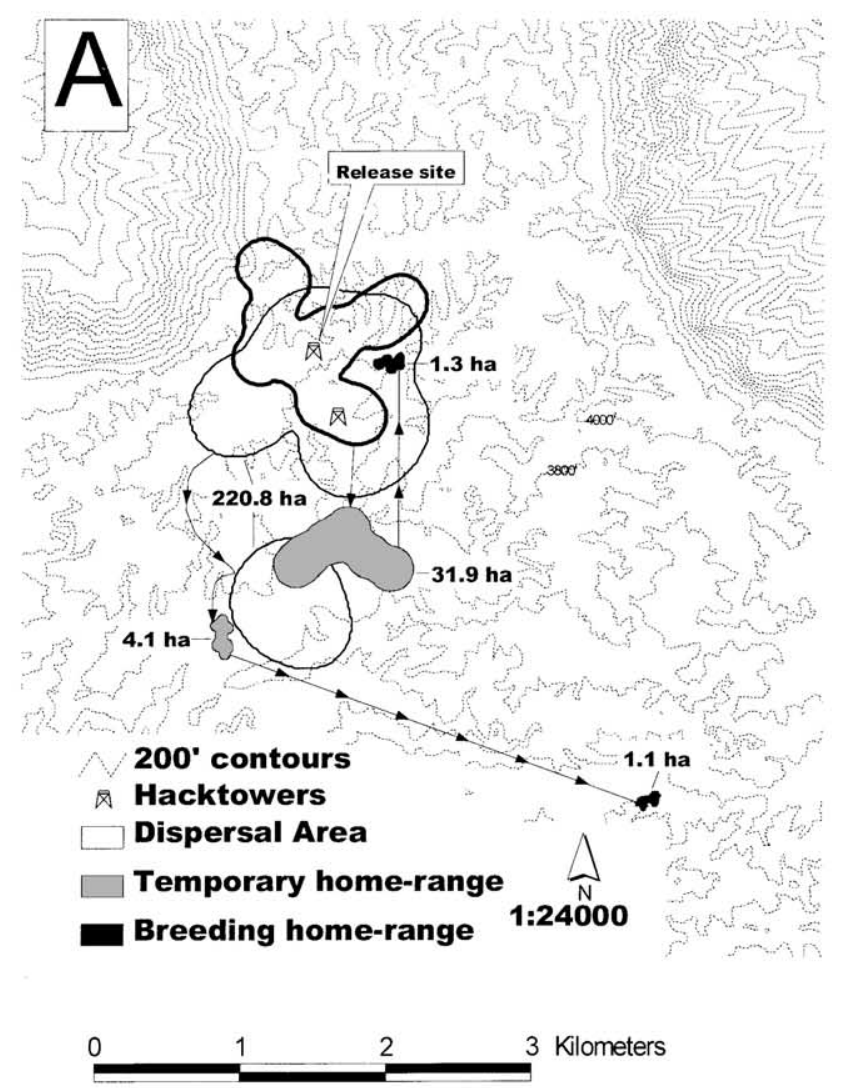

By the beginning of the breeding season (25 March 1999), we confirmed that six of seven birds had abandoned their temporary home-ranges. Three females were later relocated on breeding home-ranges 1.3, 1.7, and $3.2 \mathrm{~km}$ from their temporary home-ranges and all three were found to be paired with wild males (Table 1). Three other birds (two males, one female) flew southeast towards the core population, however we were unable to visually locate them. The remaining bird's signal (697) was lost 53 days after release (she left the area or her transmitter died) and with subsequent follow-ups in the vicinity we determined that she was not present. In all but one case, breeding home-ranges were located farther from the release site than temporary home-ranges.

All eight birds (two males and six females) that we were able to locate during the breeding season were confirmed to have paired and bred in the first season after release (USGS/BRD, unpublished data). Breeding home-ranges were small in comparison to temporary home-ranges, averaging only 1.2 ha $(\mathrm{SD} \pm 0.34$, range $0.8-1.6, n=7$, data were insufficient for one female) (Table 1). These eight breeding home-ranges were

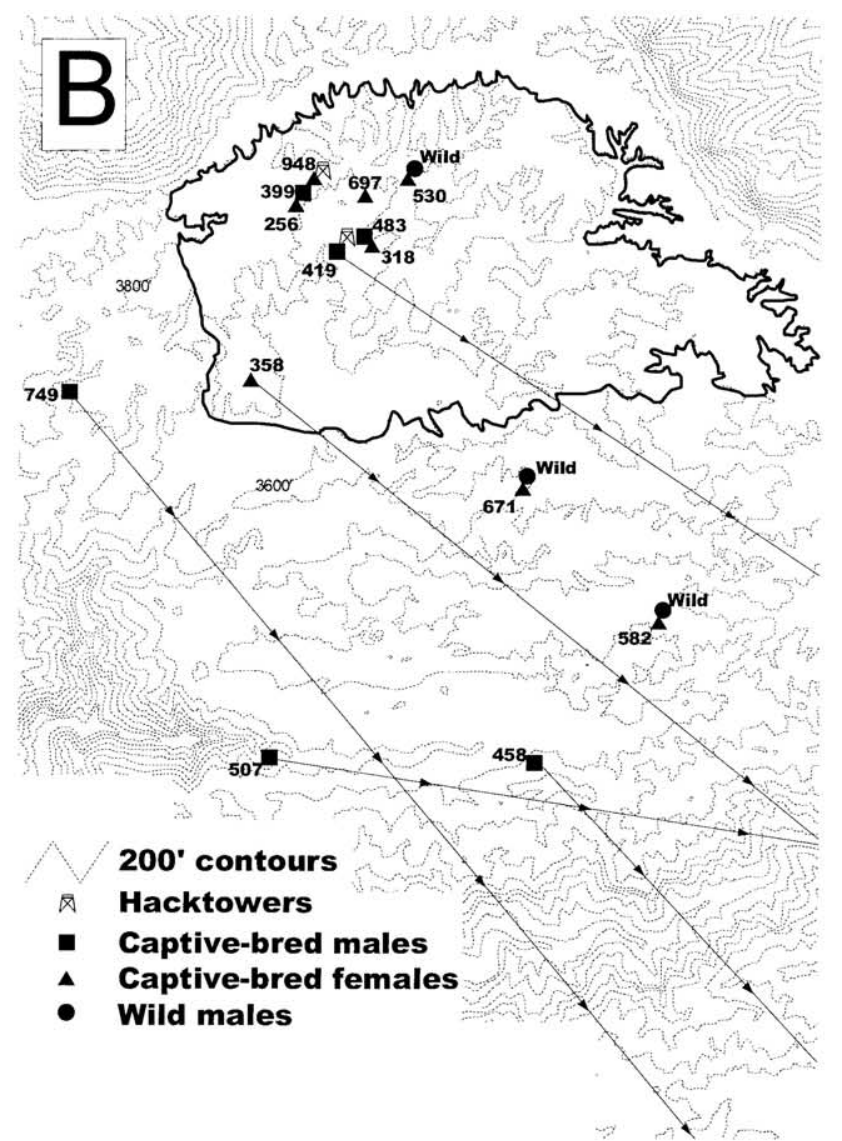

Fig. 2. (A) Examples of movements and home range establishment of two females (530 and 582) that were released into the upper Kawaikoi drainage on 9 February 1999. Arrows indicate movements from dispersal area, to temporary home-ranges, and final breeding home-ranges. (B) Final settlement locations of 14 captive-bred Puaiohi released into the upper Kawaikoi drainage Januarya-February 1999. Outline represents boundary of drainage (4000 ft elevation contour) area targeted for repopulation via reintroduction efforts. Arrows represent last known bearing for birds that left their temporary home-ranges. Bird 419 dispersed over $4 \mathrm{~km}$ within $24 \mathrm{~h}$ of release. Note bird 697 left the study area in an unknown direction. 
located on average $1.0 \mathrm{~km}$ ( $\mathrm{SD} \pm 1.4$, range $20 \mathrm{~m}-3.9$ $\mathrm{km}$ ) from the bird's release site. If the other six birds also established breeding home-ranges, they would have been located over $4 \mathrm{~km}$ from the release hacktower.

Five of the 14 released birds (35.7\%, one pair and one polygynous trio) established breeding home-ranges within $50 \mathrm{~m}$ of the hacktowers and returned for supplemental food after release (Table 1 and Fig. 2B). These five birds were from all three releases. The sixth bird that bred in the drainage $500 \mathrm{~m}$ from release site was from our second release. There was some evidence for intraspecific interference: a male and female (that later paired) exhibited agonistic behavior toward another male on at least two occasions at a hacktower up to 4 days after release. The harassed male dispersed over $2 \mathrm{~km}$ from the hacktower 3 days after this aggression was observed.

Thus, as of 22-days post release, $71.4 \%$ of all released birds $(100 \%$ of females and $33 \%$ of males) remained within the lower Kawaikoi drainage. However, by the beginning of the breeding season, four additional females had dispersed to breeding territories outside of the target area, and the release effort resulted in six of the 14 released birds $(42.8 \%, 50 \%$ of females, $33 \%$ of males) remaining in the release drainage (Table 1). Six of the seven birds that dispersed from the drainage were known to have headed southeast toward the wild population and two females that were later located were found to be paired with wild males (Table 1 and Fig. 2B).

\section{Discussion}

\subsection{Survival}

The post-release survival of $100 \%$ to 8 weeks is remarkable among passerine reintroductions. Reintroduction cohorts often suffer a period of high mortality following release (reviewed in Section 1). Raptor predation has been cited as a significant cause of mortality in reintroduction studies (Wilson et al., 1992; Snyder et al., 1994) and although two known avian predators of passerines exist in the Alakai swamp (barn owl and pueo), no birds we were able to monitor were lost to raptors during this study. Behaviorally, puaiohi are well adapted to avoid avian predation based on skulking, alarm calls, and inconspicuousness in the dense vegetation (Snetsinger et al., 1999), and apparently captivebreeding has not caused the species to lose these traits. Mammalian predators were also not a cause of puaiohi mortality during the establishment phase. However, once the breeding season began, two females and their associated young were killed at the nest by rats (USGS/ $\mathrm{BRD}$, unpublished data). Rats, if not controlled, may contribute to significant breeding season losses in reintroduced and wild puaiohi, threatening the overall recovery effort.

\subsection{Dispersal and home-range establishment}

Captive-bred released puaiohi followed three general patterns: $14.2 \%$ immediately dispersed greater than 3 $\mathrm{km}$ from release site within $24 \mathrm{~h} ; 35.7 \%$ immediately established a home-range on which they later bred; and $50.1 \%$ established a temporary home-range for a period of time and then dispersed at the start of the breeding season (we later located three in established breeding home-ranges). We are uncertain of the significance of these discrete temporary home-ranges. Wild puaiohi in the Alakai swamp appear to maintain their breeding home-ranges throughout the year (Snetsinger et al., 1999), so we have no reason to believe that this homerange shift was part of a normal seasonal pattern for this species. It may be part of the typical behavior pattern for wild dispersing juveniles, although no field data exist to confirm this. There were no predictable differences between temporary and breeding home-ranges, which varied in topography, habitat, nesting cliffs, and food availability. Notably, however, all five birds that did not shift home-ranges at the start of the breeding season were observed with another bird of the opposite sex on a regular basis, while all eight of the birds with temporary home-ranges were unpaired. Although characteristics of the home-range might be expected to influence the probability that a bird would be paired, we speculate that the proximate cause for shifting homeranges at the start of the breeding season was a scarcity of breeding partners. That is, we speculate that the dispersal of birds out of the release area at the start of the breeding season was a result of low puaiohi density and low availability of mates within the release area. In support of this, of the three females that established a temporary home-range and were later observed during the breeding season, all were found mated to wild males and nesting. Two other birds that were not visually located, were triangulated consistently in an area of high puaiohi densities. If mate availability does in fact influence fidelity to the release site, the presence of puaiohi in the release site, especially unpaired birds, may promote higher site fidelity for birds released in the future.

The results of this study have important implications for the captive breeding and release program. Current methods of transporting birds, acclimatizing them to the release area, providing supplemental food, and releasing and monitoring birds (Kuehler et al., 2000) are clearly adequate to ensure high survival of the birds. The fact that birds had equal survival regardless of their use of supplemental food suggests that supplemental food may not be necessary for reintroduction success, as has been previously been shown for saddlebacks (Armstrong et al., 1999). However, because provisioning is relatively easy and inexpensive, we do not suggest discontinuing it 
unless further study indicated drawbacks (e.g. disease transmission or attracting potential predators).

Most birds $(75 \%)$ that dispersed out of the drainage were found or last detected in the direction or vicinity of the wild population (Fig. 1). Whether this reflects conspecific attraction or habitat selection is unclear. However, the fact that fully $57 \%$ left the release area has several implications: first, repeated releases of birds in the same area will probably be necessary to succeed in establishing a second, self-sustaining population of puaiohi in the Kawaikoi drainage. If our hypothesis that dispersal out of the area was directly related to the availability of mates, then site fidelity could be expected to improve over the coming years. Secondly, our findings demonstrate that the newly-established population of puaiohi is not genetically isolated. Dispersal distances of captive-reared released birds are great (up to and over $4 \mathrm{~km}$ ), and pairings between captive-bred and wild birds have been observed (USGS/BRD, unpublished data). Although small population guidelines recommend that captive breeding programs maintain a minimum of $90 \%$ of original genetic variation, the observed potential gene flow between captive-bred and wild birds suggests that a small captive-breeding program may be sufficient at present. As long as the core population is stable, additional founder stock can be collected from the wild, to augment the genetic diversity in captivity if necessary.

Ultimately, the solution to halting the decline of most endangered species is preventing the loss and degradation of habitat and addressing concerns of ecosystem integrity. However, we must intensely manage populations of endangered species until such time as effective habitat management tools can be developed and implemented. The success of this reintroduction bodes well for the development of and application of these techniques to puaiohi and other endangered Hawaiian passerines, and we recommend that captive propagation efforts continue alongside large-scale attempts at ecosystem preservation and restoration.

\section{Acknowledgements}

We owe a debt of gratitude to Steve Fancy and Karen Rosa, who were part of the initial group that conceived of this project and guided it through its initial stages. Tom Snetsinger and Christina Herrmann conducted the ground-breaking field work that laid the foundation for current Puaiohi recovery efforts. The following individuals contributed countless hours of grueling field work to obtain the monitoring data presented here: Nathan Gregory, Carol Erwin, Barabara Schmeling, and Andrea Erichsen. We thank the Hawaii Division of Forestry and Wildlife for permission to work on their land, and owe thanks to the Hawaii Division of
Forestry and Wildlife and Kokee Natural History Museum for logistical and local support. We thank Aloha Airlines for their helpful support with transporting birds. Funding to support the captive propagation and release were provided by The Peregrine Fund, Zoological Society of San Diego, US Fish and Wildlife Service, Club 300 of Sweden, The G.N. Wilcox Foundation, The Anne Sinclair Foundation of the Hawaii Community Foundation, The Geraldine Dodge Foundation, The Kaytee Avian Foundation, and the Wallace Research Foundation. Funding to support the prerelease predator control and post-release monitoring was provided by the Hawaii Division of Forestry and Wildlife, US Fish and Wildlife Service, and Biological Resources Division-USGS. We thank Richard Camp, Jay Nelson, Steve Fancy, and an anonymous reviewer for reviewing and improving earlier versions of the manuscript.

\section{References}

Allen, D.H., Franzreb, K.E., Escano, R.E.F., 1993. Efficacy of translocation strategies for red-cockaded woodpeckers. Wildlife Society Bulletin 21, 155-159.

Armstrong, D.P., Castro, I., Alley, J.C., Feenstra, B., Perrott, J.K., 1999. Mortality and behaviour of hihi, an endangered New Zealand honeyeater, in the establishment phase following translocation. Biological Conservation 89, 329-339.

Armstrong, D.P., Craig, J.L., 1995. Effects of familiarity on the outcome of translocations. I. A test using saddlebacks Philesturnus carunculatus rufusater. Biological Conservation 71, 133-141.

Atkinson, C.T., Woods, K.L., Dusek, R.J., Sileo, L., Iko, W.M., 1995. Wildlife disease and conservation in Hawaii: pathogenicity of avian malaria (Plasmodium relictum) in experimentally infected Iiwi (Vestiaria coccinea). Parasitology 111, 59-69.

Atkinson, C.T., Lease, J.K., Drake, B.M., Shema, N.P., 2001. Pathogenicity, serological responses, and diagnosis of experimental and natural malarial infections in native Hawaiian thrushes. Condor $103,209-218$

Atkinson, I.A.E., 1977. A reassessment of factors, particularly Rattus rattus $\mathrm{L}$., that influenced the decline of endemic forest birds in the Hawaiian Islands. Pacific Science 31, 109-133.

Beyer, D.E., Haufler, J.B., 1993. Diurnal versus 24-hour sampling of habitat use. Journal of Wildlife Management 58, 178-180.

Castro, I., Alley, J.C., Empson, R.A., Minot, E.O., 1995a. Translocation of hihi or stitchbird Notiomystis cincta to Kapiti Island, New Zealand: transfer techniques and comparison of release strategies. In: Serena, M. (Ed.), Reintroduction Biology of Australian and New Zealand Fauna. Surrey Beatty and Sons, Chipping Norton, Australia, pp. 113-120.

Castro, I., Minot, E.O., Alley, J.C., 1995b. Feeding and breeding behaviour of hihi or stitchbirds Notiomystis cincta recently transferred to Kapiti Island, New Zealand, and possible management alternatives. In: Serena, M. (Ed.), Reintroduction Biology of Australian and New Zealand Fauna. Surrey Beatty and Sons, Chipping Norton, Australia, pp. 121-128.

Clarke, M.F., Schedvin, N., 1997. An experimental study of the translocation of noisy miners, Manorina melanocephala and difficulties associated with dispersal. Biological Conservation 80, 161167. 
Cuddihy, L.W., Stone, C.P., 1990. Alterations of Native Hawaiian Vegetation: Effects of Humans, their Activities and Introductions. University of Hawaii Press, Honolulu, HI.

Deat, A., Mauget, C.R., Maurel, D., Sempere, A., 1980. The automatic, continuous, and fixed radio tracking system of the Chize Forest: theoretical and practical analysis. In: Amlaner Jr., C.J., Macdonald, D.W. (Eds.), A Handbook on Biotelemetry and Radio Tracking. Pergamon Press, Oxford, England, pp. 439451.

Dougill, S.J., Johnson, L., Banko, P.C., Goltz, D.M., Wiley, M.R., Semones, J.D., 2000. Consequences of antenna design in telemetry studies of small passerines. Journal of Field Ornithology 71, 385388.

Ecological Software Solutions, LOAS ${ }^{\mathrm{TM}}$, 1999. Location of a Signal User's Guide. Ecological Software Solutions, Sacramento, CA.

Engilis Jr., A., Pratt, T.K., 1989. Kauai forest bird survey yields surprises and disappointments. Hawaii Wildlife Newsletter 4, 1-10.

Fancy, S.G., Snetsinger, T.J., Jacobi, J.D., 1997. Translocation of the palila, an endangered Hawaiian honeycreeper. Pacific Conservation Biology 3, 39-46.

Fancy, S.G., Nelson, J.T., Harrity, P., Kuhn, J., Kuhn, M., Kuehler, C., Giffin, J,G., 2001. Reintroduction and translocation of omao: a comparison of methods. In Scott, J.M., Conant, S., Van Riper III, C. (Eds.), Evolution, Ecology, Conservation, and Management of Hawaiian Birds: A Vanishing Avifauna. Studies in Avian Biology 22, 347-353

Giambelluca, T.W., Nullet, M.A., Schroeder, R.A., 1986. Rainfall Atlas of Hawai'i (Report R76). Department of Land and Natural Resources, Honolulu, Hawaii.

Griffith, B., Scott, J.M., Carpenter, J.W., Reed, C., 1989. Translocation as a species conservation tool: status and strategy. Science 245 , $477-480$

Kuehler, C., Lieberman, A., Oesterle, P., Powers, T., Kuhn, M., Kuhn, J., Nelson, J.T., Snetsinger, T., Herrman, C., Harrity, P., Tweed, E., Fancy, S., Woodworth, B., Telfer, T., 2000. Development of restoration techniques for Hawaiian thrushes: collection of wild eggs, artificial incubation, hand-rearing, captive-breeding, and reintroduction to the wild. Zoo Biology 19, 263-277.

Kurzejeski, E.W., Root, B.G., 1989. Home range, movements, and habitat use by reintroduced ruffed grouse in northern Missouri. Wildlife Soceity Bulletin 17, 106-111.

Lenth, R.V., 1981a. On finding the source signal. Technometrics 23, $149-154$.

Lenth, R.V., 1981b. Robust measures of location for directional data. Technometrics 23, 77-81.

Lovegrove, T.G., 1992. Effects of Introduced Predators on the Saddleback (Philesturnus carunculatus) and Implications for Management. PhD Thesis, University of Auckland, Aukland, New Zealand.

Munro, G.C., 1944. Birds of Hawaii. Bridgeway Press, Honolulu, Hawaii.

Musil, D.D., Connelly, J.W., Kerry, P.R., 1993. Movements, survival, and reproduction of sage grouse translocated into central Idaho. Journal of Wildlife Management 57, 85-91.

Nelson, J.T., Woodworth, B.L., Fancy, S.G., Lindsey, G.D., Tweed, E.J., 2002. Effectivenes of rodent control and monitoring techniques for a montane rainforest. Wildlife Society Bulletin 30, 82-92.
Olson, S.L., 1989. Extinction in islands: man as a catastrophe. In: Webster, D., Pearl, M.C. (Eds.), Conservation for the Twenty-first Century. Oxford University Press, New York, pp. 50-53.

Perkins, R.C.L., 1903. Vertebrata. In: Sharp, D. (Ed.), Fauna Hawaiiensis, Vol. I, Part IV. The University Press, Cambridge, UK, pp. 365-466.

Pratt, H.D., 1994. Avifaunal change in the Hawaiian islands, 1893 1993. In: Jehl, Joseph r. Jr., Johsnson, Ned K. (Eds.), A Century of Avifaunal Change in Western North America: Proceedings of an International Symposium at the Centennial Meeting of the Cooper Ornithological Society, Sacramento, California, 17 April 1993, 1994. Studies in Avian Biology, Vol. 15, pp. 103-118.

Pyle, R.L., 1993. Hawaiian Islands region. American Birds 47, 11521153.

Rappole, J.H., Tipton, A.R., 1991. New harness design for attachment of radio-transmitters to small passerines. Journal of Field Ornithology $62,335-337$.

Reynolds, M.H., Snetsinger, T.J., Herrmann, C.M., 1997. Kauai's endangered solitaires: update on population status and distribution 1996. Transactions of the Western Section of the Wildlife Society $33,49-55$.

Richardson, F., Bowles, J., 1964. A survey of the birds of Kauai, Hawaii B.P. Bishop Museum Bulletin No. 227. Bishop Museum Press, Honolulu, HI

Rudolph, C.D., Conner, N.C., Carrie, D.K., Schaefer, R.R., 1992. Experimental reintroduction of red-cockaded woodpeckers. Auk 109, 914-916

Sanz, V., Grajal, A., 1998. Successful reintroduction of captive-raised yellow-shouldered Amazon parrots on Margarita Island, Venezuela. Conservation Biology 12, 430-441.

Scott, J.M., Mountainspring, S., Ramsey, F.L., Kepler, C.B., 1986. Forest bird communities of the Hawaiian Islands: their dynamics, ecology, and conservation. Studies in Avian Biology (9) 1-431.

Short, J., Bradshaw, S.D., Giles, J., Prince, R.I.T., Wilson, G.R., 1992. Reintroduction of macropods (Marsupialia: Macropodoidea) in Australia - a review. Biological Conservation 62, 189-204.

Snetsinger, T.J., Wakelee, K.M., Fancy, S.G., 1999. Puaiohi (Myadestes palmeri). In: Poole, A., Gill, F. (Eds.), The Birds of North America, No. 461. The Birds of North America, Philadelphia, PA.

Snetsinger, T.J., Fancy, S.G., Simon, J.C., Jacobi, J.D., 1994. Diets of owls and feral cats in Hawaii. Elepaio 54, 47-50.

Snyder, N.F.R., Koenig, S.E., Koschmann, J., Snyder, H.A., Johnson, T.B., 1994. Thick-billed parrot releases in Arizona. Condor 96, 845862.

USGS/BRD, 1999. Animal Movement Analysis ArcView Extension. United States Geological Survey, Biological Resources Division, Alaska Biological Science Center, Glacier Bay Field Station, Alaska.

van Riper III, C., van Riper, S.G., Goff, M.L., Laird, M., 1986. The epizootiology and ecological significance of malaria in Hawaiian land birds. Ecological Monographs 56, 327-344.

Warner, R.E., 1968. The role of introduced diseases in the extinction of the endemic Hawaiian avifauna. Condor 70, 101-120.

Wilson, R.J., Drobney, R.D., Hallett, D.L., 1992. Survival, dispersal, and site fidelity of wild female ring-necked pheasants following translocation. Journal of Wildlife Management 56, 79-85s. 